\title{
Provenance, transport and diagenesis of sediment in polar areas: a case study in Profound Lake, King George Island, Antarctica
}

\author{
Ana C. Hernández ${ }^{\mathrm{a}, \mathrm{b}}$, Joaquin Bastias $\mathbb{D}^{\mathrm{c}, \mathrm{d}}$, Daniela Matus ${ }^{\mathrm{e}}$ \& William C. Mahaney ${ }^{f}$ \\ aCentro de Oceanología y Estudios Antárticos, Instituto Venezolano de Investigaciones Científicas, Caracas, Venezuela; bFacultad de \\ Ingeniería. Escuela de Geología, Minas y Geofísica. Departamento de Geología, Universidad Central de Venezuela. Ciudad Universitaria, \\ Caracas, Venezuala; 'Department of Earth Sciences, University of Geneva, Geneva, Switzerland; 'Departamento de Geología, Universidad

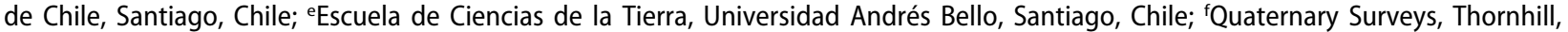 \\ Ontario, Canada
}

\begin{abstract}
Detailed scanning electron microscopy (SEM) micro-texture and mineralogical analysis of lacustrine sediment recovered from Profound Lake (also known as Uruguay Lake), Antarctica, was conducted in the foreland area of the Collins Glacier, King George Island. Very coarse and coarse sand grade size fractions $(2 \mathrm{~mm}-600 \mu \mathrm{m})$ were examined with SEM/ energy dispersive spectrometry, while the total sand fraction and fines (silt + clay) were examined using x-ray diffraction to determine relationships to source rock, weathering and transport history and long-term clay mineral weathering, all of which are poorly understood in polar areas. The mineralogy of these sediments was compared with petrographical information of the country rock to identify potential detrital sources. The association of recovered detrital minerals, sometimes strongly pre-weathered, supports release from source rock of basaltic and andesitic compositions. The micro-texture analysis of quartz, magnetite and various plagioclase grains show micro-features that reveal a complex weathering-diagenesis history tentatively extending into the Paleogene. The bedrock was eroded mostly by glacial processes and mechanical action presumed to result from glacial crushing. Alteration minerals, likely the product of pre-weathering, are probably sourced from weathered bedrock during contact with the sub-aerial atmosphere prior to entrainment. However, amorphous silica precipitation indicates weathering subsequent to glacial erosion from the source bedrock. Cracks of variable dimensions are mostly characteristic of either frost weathering or glacial transport, and involve mechanical and chemical processes.
\end{abstract}

\section{KEYWORDS}

lake sediment; micro-texture characteristics; hydrothermal alteration; quartz grain micromorphology; environmental interpretation

\section{ABBREVIATIONS}

EDS: energy dispersive spectrometry; SEM: scanning electron microscopy; XRD: x-ray diffraction

\section{Introduction}

Little is known about sediment deposited in polar lacustrine environments; in particular, evidence is lacking on bedrock release, transport processes and ultimate sedimentation (Mahesh et al. 2015). Although much of the Antarctic continent is covered with ice, some locations, such as the archipelago of the South Shetlands, contain freshwater lakes. One of these is Profound Lake on King George Island, which is a perennial ice-covered deepwater lake (Fig. 1). Because Profound Lake is one of the largest freshwater bodies of the region and the deepest reported in the Fildes Peninsula (Mäusbacher et al. 1989), it is an ideal place to study grain transport and sedimentation history in a maritime sub-polar locality.

Sediment deposited in lakes of the peripheral zones of Antarctica represent a great potential to understand different sedimentary processes under harsh climatic conditions (Mahesh et al. 2015). Sediment is brought into the lake basin by release from bedrock; glacial, aqueous and aeolian transport; shoreline erosion and mass movement. Hence, the characteristics recorded in the surface of sediments depend upon several factors, such as source, mechanisms of transport, conditions at the depositional site within the basin and geological processes during transport and deposition of the material (e.g., weathering intensity, diagenesis) at both macro- and microscales (Last 2001). In addition, in situ bearing minerals are known to have formed post-depositionally in lake sediment either by inorganic or biological processes (Vos et al. 2014). Understanding sediment diagenesis in the Earth's cold regions is important to understand rates of production of alteration products, particularly oxides-hydroxides and clay minerals, which form palaeoenvironmental archives (Mahaney \& Schwartz 2016). Furthermore, the mix of a sub-polar locality and unique mica-bearing lithology provides a setting in which to investigate clay mineral genesis and to reconstruct the probable weathering pathway of $1: 1(\mathrm{Si}: \mathrm{Al}=1: 1)$ clay minerals. Clay mineral analysis makes a valuable contribution to reconstructing glacial history (Ehrmann 1998). 
Quartz, a stable mineral with a high resistance to weathering (e.g., Krinsley \& Doornkamp 1973; Mahaney 2002), makes up $97 \%$ of siliciclastic sand (Pettijohn et al. 1987), and offers a long-lived recorder of damage inflicted during transport throughput in many different environments. Because quartz has no definite cleavage planes, it reacts to collision with other particles by producing conchoidal fractures similar to broken glass (Peternecht \& Tietz 2011), which is what makes its sole appearance in a suite of grains indefinite as to a glacial origin. The microtexture conservation capacity of quartz provides a broad spectrum of micro-features that contain relevant information for regions with high erosion and slow weathering, such as Antarctica (Mahaney, Dohm et al. 2001; Mahaney et al. 2009; Mahaney \& Schwartz 2016). However, quartz grains in glacial deposits tend to record polygenetic histories (Mahaney \& Schwartz 2016; Woronko 2016), sometimes recovering multiple events of grain impactweathering over long time periods (Mahaney 2002). Moreover, the enrichment of different mineral phases can be determined via the study of mineral associations, all of which are controlled by composition of the source rock, subsequent weathering history followed by transport, and eventual deposition (e.g., Biscaye 1965). In addition, the study of different minerals and their response to different types of weathering may provide relevant information related to paleoenvironments, and sometimes to the string of environmental systems throughput that grains have followed after release from bedrock. For example, hydrothermal events may affect chemical weathering and such signatures may be written into recovered sands, along with glacial, aeolian and fluvial transport signatures, followed by biological activity during diagenesis, which may generate products such as diatoms. Although frost weathering is considered to be the most common mechanical weathering process in polar regions, it is still poorly understood at the single grain level, as is its relationship to chemical weathering.

Profound Lake (also known as Uruguay Lake) is situated to the north-east of Fildes Peninsula, in the extreme south-western region of King George Island (Fig. 1). It is the second largest and deepest reported lake in the Fildes Peninsula (Mäusbacher et al. 1989). This region has significance for palaeoclimatic and palaeoenvironmental studies because it contains active glacial, aeolian, fluvial and lacustrine systems. However, the lacustrine sediments of this region are the main focus of study as they preserve sediment at the end of a long weathering-release and transport history.

This study provides detailed information on the transport and diagenetic history of sediments accumulated in Profound Lake. Elucidation of these processes was achieved by studying the mineralogy, chemistry and micro-texture assemblage of selected samples sourced from local bedrock, sites within the nearby Collins Glacier moraine fronting the ice, and ground moraine between the ice front and the lake, with all or most sediment subjected to fluvial and aeolian transport over restricted but unknown distances. The analysis consists of detrital mineralogy and geochemistry (XRD and SEM/EDS) combined with morphological micro-texture studies of quartz and other widely present minerals to present the full process of bedrock release, throughput of grains in various environmental systems, to final residence in the lake shore. We emphasize the role of chemical weathering in these cold

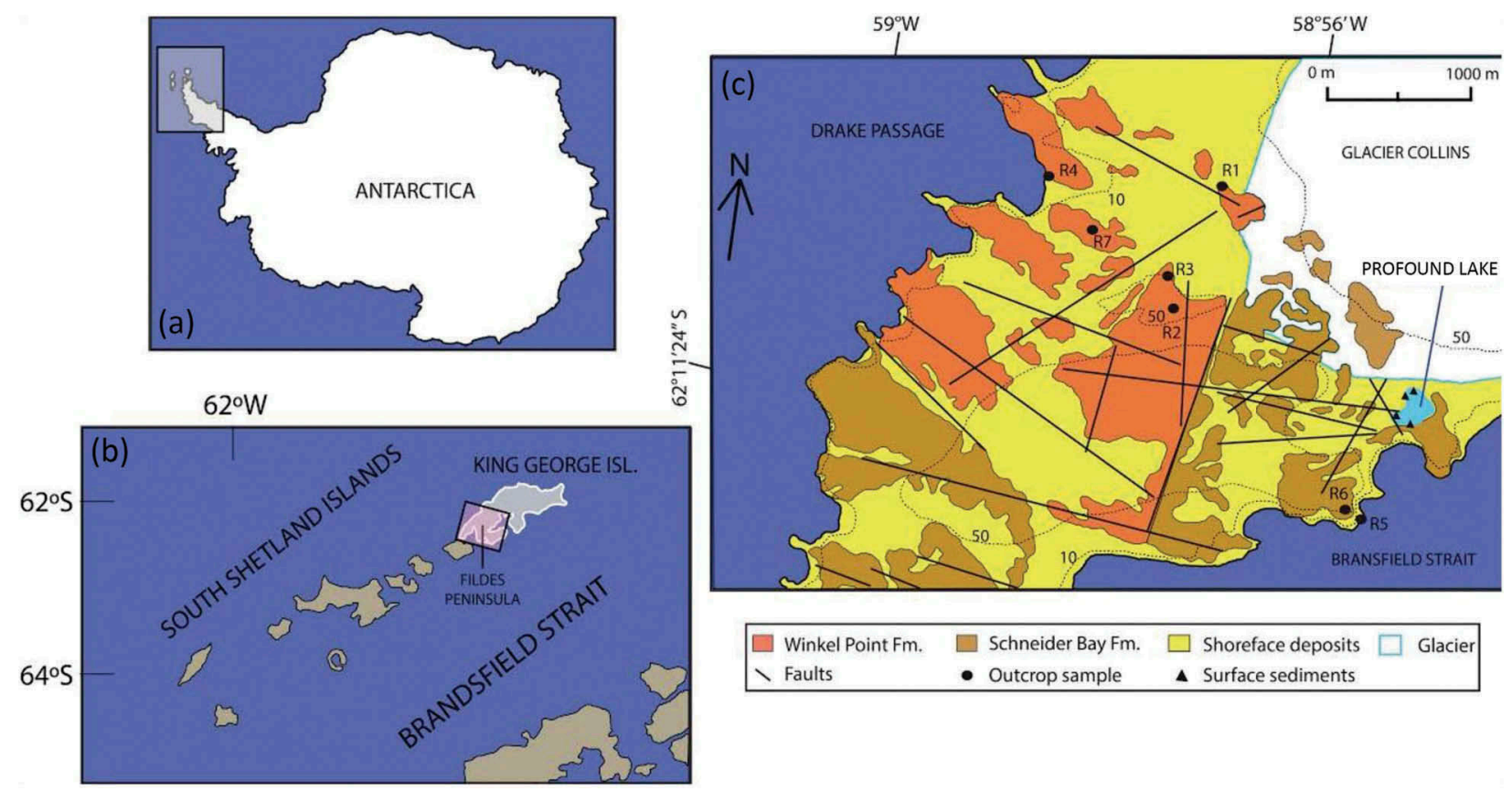

Figure 1. Geological map of study area with sample locations (modified from Machado et al. 2005). 
conditions, which is not evident in macro-scale studies but is reported here through these micro-scale analyses.

\section{Geological setting}

King George $\left(62^{\circ} 10^{\prime} \mathrm{S}, 58^{\circ} 59^{\prime} \mathrm{W}\right)$ is the largest island of the South Shetland Islands. Bedrock in the area is predominantly composed of basic volcanic rocks, most of which form part of the South Shetland Islands volcanic arc (Haase et al. 2012), which records tectonic activity from $135-47$ Mya. The arc is the product of the remnant westward subduction of the Pacific Plate under the Antarctic Peninsula (e.g., Smellie et al. 1984), which produced rocks comprised of tholeiitic to calc-alkaline chemistries with bracketed ages ranging from older to younger from south-west to north-east (Haase et al. 2012). Subduction began to wane with the onset of the Palaeogene, becoming quiescent since that time. This led to an extension of the back-arc, which produced the present Bransfield Strait (Solari et al. 2008), the waterway separating the Antarctic Peninsula from the South Shetlands Islands. Profound Lake is located within the Fildes Peninsula, the most extensive coastal area free of snow in the austral summer on King George Island. Past studies indicate that the present-day warm environment dates back to about 5000 - 6000 yr B.P. (Mäusbacher et al. 1989).

Bedrock outcropping in the surrounding area of Profound Lake $\left(62^{\circ} 11.066^{\prime} \mathrm{S}, 58^{\circ} 54.413^{\prime} \mathrm{W}\right)$ (Fig. 1) consists mainly of andesite and andesitic-basaltic lavas, which correspond to the Upper Cretaceous formations of Winkel Point and Schneider Bay from the Fildes Peninsula Group (Barton 1961; Smellie 1984). The Schneider Bay Formation includes porphyritic basalt overlying basaltic andesite and andesite, whereas Winkel Point is composed mainly of basalt and basaltic andesite with inter-bedded volcanic breccia, agglomerate and tuff (Machado et al. 1998; Machado et al. 2005). Soils in the area have been classified according to the US Soil Taxonomy (Soil Survey Staff 1999) and consist mostly of cryoturbated entisols, cryosols with some gleysols, but entisols (cryorthents) with $\mathrm{Ah}-\mathrm{C}(\mathrm{ox})-\mathrm{Cu}$ profiles (Michel et al. 2014) dominate. In the Canadian Soil Classification System, these pedons would key out as Regosols (Soil Classification Working Group 1998). In addition, geochemical studies of lacustrine sediment from Fildes Peninsula indicate that local bedrock is probably the main source of sediment in Profound Lake, which contrasts with other nearby lakes that have high concentrations of some elements (Ba, Sr, P) and zeolites (Alfonso et al. 2015). Using geochemical data from local bedrock of King George Island, Monien et al. (2011) showed that short-term alterations in the regional climate during the last ca. 1750 years produced glacial advance and consequent retreat, as recorded in lacustrine and glacial sediments from Fildes Peninsula (Monien et al. 2011).

\section{Materials and methods}

\section{Sediment sampling}

The sampling of surface sediment in Profound Lake was carried out during the VI Scientific Venezuelan Expedition of 2013, and seven rock samples were collected during the 51st Chilean Antarctic Science Expedition of 2015. Four representative samples of surface sediment (upper $3 \mathrm{~cm}$ ) were collected around the Profound Lake shoreline (after removing the surface sediment cover).

The sediment samples were dried at $40^{\circ} \mathrm{C}$, disaggregated and sieved using a nylon sieve cloth to produce bulk samples. Afterward, samples were sieved again to produce coarse $(500-1000 \mu \mathrm{m})$ and very coarse $(1-2 \mathrm{~mm})$ fractions out of the bulk collected mass. These grade sizes were selected to analyse features of glacial sediments such as angularity, fractures and fragmentation, which are more pronounced and more frequently encountered in the medium and coarse fractions. Later, samples were washed with distilled water and subjected to light ultrasound for five minutes to make the mixture neutral and clean grain surfaces. The particles were randomly selected and split into two subgroups: 25 grains of quartz and 25 coarse grains of different composition. Quartz grains were selected by hand using a fine needle viewed through a binocular microscope. The surface micro-texture classification model is based on studies from Krinsley \& Doornkamp (1973), Mahaney (2002), Helland \& Holmes (1997) and Vos et al. (2014).

The fine fraction $(<2 \mu \mathrm{m})$ was separated and smeared on slides to prepare grain mounts for XRD clay analyses. To produce oriented mounts it is necessary to centrifuge clay slurries using porous clay tiles increasing peak height by 5 - 10\% (Jackson 2005), which, in this case, was deemed not necessary for mineral identification.

\section{Analytical methods}

Sample preparation for surface micro-texture grain analysis using SEM was conducted according to Trewin (1988). Grains were prepared by interspersing 50 grains of selected coarse and very coarse fractions on a specimen stub overlain with carbon as the 
conductive medium. Grain composition was verified by EDS. SEM was performed using a Hitachi FESEM4500 , while EDS was carried out on an EDAX model 8400 .

Micro-texture terminology and classification is based on Mahaney (1995), Mahaney et al. (1996), Helland \& Holmes (1997), Mahaney (2002), Immonen (2013) and Vos et al. (2014).

The fine grain size sediment (silt + clay) was analysed using a Siemens D-5005 x-ray diffractometer equipped with parallel beam geometry and $\mathrm{Cu} \mathrm{Ka}$ radiation, operated by Difracc ${ }^{\text {Plus }}$ software with a voltage of $40 \mathrm{keV}$, current of $30 \mathrm{~mA}$ and angles ranged from $5-90^{\circ}$ in 0.020 steps. The intensity was measured using the commercial software program EVA, which is contained in the Bruker-Siemens diffraction software package, Diffrac ${ }^{\text {plus }}$. Minerals were identified from their characteristic peaks at the Center of Oceanology and Antarctic Studies, Venezuela.
Petrological studies from seven outcrops adjacent to Profound Lake were conducted in order to compare source rock to sediment. The resulting thin sections were studied via optical microscopy in the Department of Geology, Andres Bello University, Chile. The rocks were classified according to their mineral composition using the classification system of Streckeisen (1976). Modal analyses were made on 200 randomly selected points. The point-count method, as described by Hutchinson (1974), was used to determine modal composition. Minerals were distinguished for each thin section.

\section{Results \\ Micro-texture and mineralogical grain characterization}

The SEM/EDS analysis shows that the sediments consist of plagioclase (the most abundant phases), followed by

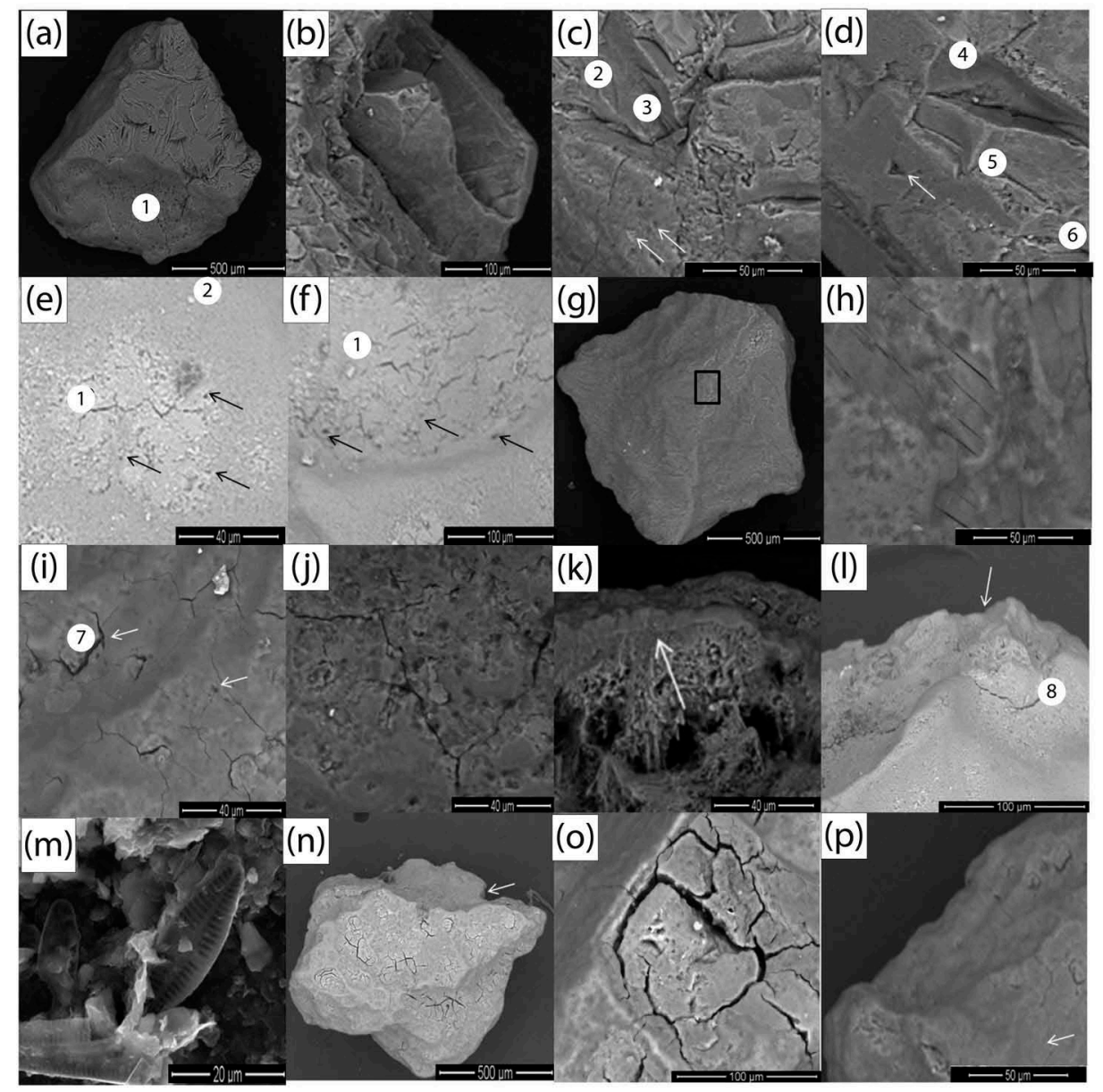

Figure 2. Selected grains of quartz: (a) angular grain with typical features of glacial grinding including sharp-fractured edges, high relief, deep trough and clay coatings (1); (b) Sharp angular outline and fracture face; (c) fresh breakage blocks (2, 3); (d) weathered breakage blocks, accompanied by small conchoidal fracture (4), straight grooves (5), curved grooves (6) and V-shaped cracks (arrow); (e) and (f), cracks and V-shaped cracks (arrow); (g) angular grain with high relief; (h) close up of (g) sub-parallel linear and micro-cracks; (i) cracks and adhering particles (7); (j) chemical dissolution and cracks; (k) thick layer of amorphous silica by precipitation; (l) edge abrasion and precipitation features $(8)$; $(\mathrm{m})$ diatoms embedded in quartz grain (Achnanthes sp.); ( $n$ ) edge abrasion and polygonal cracks; (o) polygonal cracking on the grain outside depressions; ( $p$ ) angular grain with edge abrasion and clay coating, possibly smectite (Si:Al = 2:1) composition. 
zeolite, clinopyroxene, quartz, olivine, calcite and $\mathrm{Fe}$ - $\mathrm{Ti}$ oxides (magnetite, generally Ti-rich), with small amounts of clay and accessory minerals.

Selected quartz grains shown in (Fig. 2) represent angular to sub-angular clasts subjected to sufficient stress, such as mechanical release from bedrock and glacial transport (Fig. 2a-2b, 2e-2f), but with minor overtones of aeolian, fluvial and weathering agents. Angular edges covering more than $50 \%$ of grain surfaces, as shown in Fig. 2a, 2e and $2 \mathrm{f}$, are typical of glacial crushing, although aeolian transport is known (Mahaney 2002) to produce similar grain damage although not on the scale seen here. The round facets or bulbous edges on Fig. $2 \mathrm{~b}$ may relate to minor aeolian modification at some point of transition following bedrock release or prior to glacial transport. While clay content is variable as coatings on larger particles, and generally less than $5 \%$, most clay genesis is attributed to pre-weathering in outcrop, or following release during previous interglacial periods and even earlier during warmer-wetter climate prior to the onset of cold, dry conditions.

In general, coarse sand $(500-1000 \mu \mathrm{m})$ and very coarse sand $(1-2 \mathrm{~mm})$ carry angular to sub-angular shapes, as shown in Figs. 2 and 3. The micrographs in Figs. 2 and 3 reflect different types of physical weathering, including blockage breaks presumably from bedrock release (Mahaney 2002) or from grain-tograin contact in ice, as well as chemical dissolutionetching. Quartz grains from Profound Lake exhibit a range of micro-textures, ranging from robust etching to anomalous coatings and embedded biogenic materials. These are described in Table 1. While most grain micro-features could relate to any number of specific environments, some (curved grooves, bulbous edges, $\mathrm{V}$-shaped percussion cracks, fracture faces, to name a few) are tied directly to a specific geologic process (Krinsley \& Doornkamp 1973; Mahaney 2002).

Quartz grains are characterized predominantly as having high relief commonly associated with sharp angular features (Fig. 2a, 2b, 2g), a common microtexture among glacial grains in polar areas Mahaney 1995. A relatively high percentage $(30-40 \%)$ of grains exhibit breakage blocks (Fig. 2c, d), conchoidal fractures, arcuate and polygonal cracks and craters (Fig. 2e, 2i, 2o) and edge abrasion (Fig. 2n), whereas $20-30 \%$ of grains show deep troughs and V-shaped cracks (Fig. 2e). Grooves and sub-parallel linear fractures (Fig. 2h) are least abundant (Fig. 2b). Adhering particles are present on the majority of grains analysed $(>50 \%)$, often with feldspathic and oxide compositions with $5-20 \mu \mathrm{m}$ grain size material indicating primary and secondary mineral origins. These are presumed to result from glacial grinding (Fig. 2i) (Smalley 1966), suggesting that at least 50\% of the grains analysed spent some time in glacial transit.

Chemical micro-textures are present as solution pits and also as dissolution etching (Fig. 2j), precipitation of amorphous silica (Fig. 2k) and coatings of oxides-hydroxides and clays (Fig. 2p). Embedded diatoms in quartz grains (Fig. $2 \mathrm{~m}$ ) are typical of cold water and have also been reported in this lake by Schmidt et al. (1990), all illustrated by host grains (i.e., quartz), with adhering biogenic forms illustrative

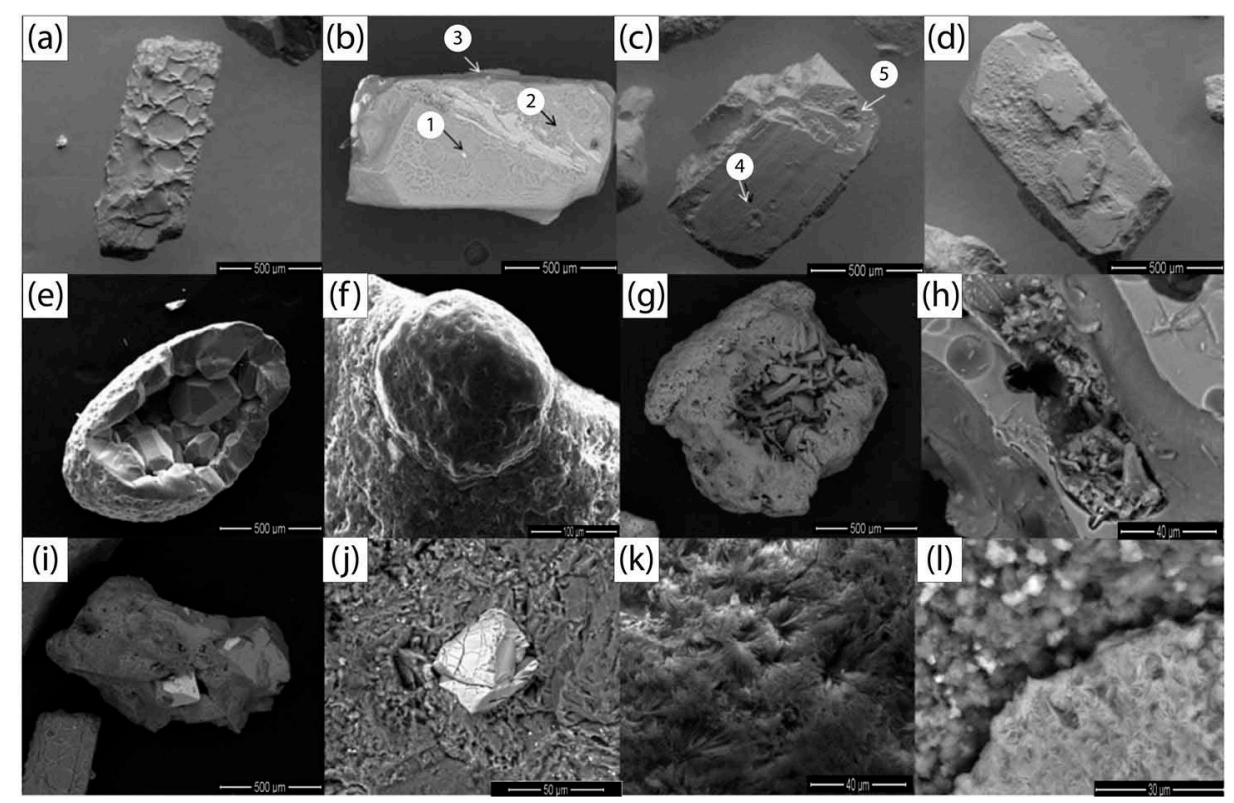

Figure 3. (a) Anorthoclase with intervesicular walls; (b) plagioclase with apatite crystals (1) and small adhering particles (2, 3); (c) plagioclase with dissolution etching $(4,5)$; (d) plagioclase with precipitation coating; (e) euhedral analcime with clay coating; ( $f$ ) analcime with solution etching; (g) tabular crystals of clinoptilolite-heulandite; (h) probable clinoptilolite in vesicle rocky fragment; (i) and (j) cracks and fractured faces in magnetite; (k) and (I), clay minerals. 
Table 1. Mineralogical descriptions. Semi-quantitative amounts notated below.

\begin{tabular}{|c|c|c|c|}
\hline Micro-textures & Characteristics & Occurrence & References \\
\hline $\begin{array}{r}\text { Conchoidal } \\
\text { fractures }\end{array}$ & Smooth curved fractures & $* * * *$ & $\begin{array}{l}\text { Mahaney 2002; Woronko 2012; Vos et al. 2014; Woronko \& Pisarska-Jamroży } \\
2016\end{array}$ \\
\hline Curved grooves & $\begin{array}{l}\text { Curved grooves } \\
\quad<10 \mu \mathrm{m}\end{array}$ & * & Mahaney 1995a; Mahaney 2002 \\
\hline Straight grooves & Linear grooves & * & Mahaney 1995a; Mahaney 2002 \\
\hline Deep troughs & Grooves $>10 \mu \mathrm{m}$ & $* *$ & Mahaney 1995a; Mahaney 2002 \\
\hline $\begin{array}{l}\text { V-shaped } \\
\text { percussion } \\
\text { cracks }\end{array}$ & $\begin{array}{l}\text { V-shaped features with variable size } \\
\text { and depth }\end{array}$ & $* * *$ & Mahaney 2002 \\
\hline Fracture face & Fresh fractures & $* * * *$ & Mahaney 1991; Mahaney 2002; Vos et al. 2014 \\
\hline $\begin{array}{l}\text { Sharp angular } \\
\text { features }\end{array}$ & Sharp edges on grain & $* * * * *$ & Mahaney 2002; Woronko 2012; Vos et al. 2014 \\
\hline $\begin{array}{l}\text { Sub-parallel } \\
\text { linear features }\end{array}$ & $\begin{array}{l}\text { Linear fractures } \\
\text { on grain }\end{array}$ & * & Mahaney 1991; Mahaney 2002; Vos et al. 2014 \\
\hline $\begin{array}{l}\text { Particles } \\
\text { adhering }\end{array}$ & Variable size and composition & $* * * * *$ & Mahaney 2002; Vos et al. 2014 \\
\hline Breakage blocks & $\begin{array}{l}\text { Space represented by removal of } \\
\text { blocks of variable size }\end{array}$ & $* * * *$ & $\begin{array}{l}\text { Helland et al. 1997; Van Hoesen \& Orndorff 2004; Woronko \& Hoch 2011; } \\
\quad \text { Woronko 2012; Woronko \& Pisarska-Jamroży } 2016\end{array}$ \\
\hline Edge abrasion & $\begin{array}{l}\text { Rounded edges } \\
\text { on grain }\end{array}$ & $* * * * *$ & Helland et al. 1997; Immonen 2013 \\
\hline $\begin{array}{l}\text { Cracks and } \\
\text { craters }\end{array}$ & Variable size & $* * * *$ & Helland et al. 1997; Immonen 2013 \\
\hline $\begin{array}{l}\text { Precipitation } \\
\text { features }\end{array}$ & Coatings on grain & $* * * *$ & $\begin{array}{l}\text { Whalley \& Krinsley 1974; Mahaney 2002; ; Woronko 2012; Vos et al. 2014; } \\
\text { Woronko \& Pisarska-Jamroży } 2016\end{array}$ \\
\hline Dissolutions & Solution crevasses and cavities & $* * *$ & Whalley \& Krinsley 1974; Mahaney 2002 \\
\hline High relief & Topographically irregular surface & $* * * * *$ & Mahaney 2002; Vos et al. 2014 \\
\hline
\end{tabular}

of diagenesis. Diatom genesis involved precipitation of $\mathrm{Si}$, demonstrating dissolution of $\mathrm{SiO}_{2}$ in cold water and presumably occurring rapidly following glaciation.

Plagioclase grains of variable composition were identified in most sample splits and nearly always of Ca-plagioclase species, including bytownite, labradorite and anorthoclase. These are highly vesiculated crystals with sharp intervesicular walls, sometimes with breaking surfaces (Fig. 3a). Adhering particles consist of apatite, magnetite and augite crystals (Fig. 3b), the last typical of the tholeiitic rock series. Plagioclase shows frequent replacement by clay minerals (Fig. 3c), another illustration of chemical weathering in extreme environments. Hydrolysis removed the metal cations, which were necessary for the formation of various clay minerals on the $\mathrm{Si}$ / Al remaining as wreckages. These wreckages, however, are lacking deep, etched pits, which implies a weak dissolution of plagioclase (Fig. 3c, d) and raises the question as to whether the clay coatings were inherited from pre-weathering or were formed during recrystallizing in situ.

Zeolites identified by SEM include analcime, heulandite-clinoptilolite series, with EDS analysis indicating the grains to be Na-rich, with minor

Table 2. Mineralogical descriptions.

\begin{tabular}{|c|c|c|c|}
\hline \multirow[b]{2}{*}{ Minerals } & \multicolumn{2}{|r|}{ Occurrences-sediments } & \multirow{2}{*}{$\begin{array}{l}\text { Occurrence in rocks } \\
\text { Petrological analysis }\end{array}$} \\
\hline & $\begin{array}{l}\text { X-ray analysis } \\
\text { concentration }^{\mathrm{a}}\end{array}$ & SEM analysis & \\
\hline Plagioclase & $* * * * *$ & $\begin{array}{l}\text { Dissolutions } \\
\text { and etched pits } \\
\text { on surface }\end{array}$ & $\begin{array}{l}\text { Phenocrysts altered to pseudomorphs of zeolites } \\
\text { and clay minerals }\end{array}$ \\
\hline $\begin{array}{l}\text { Clinoptilolite- } \\
\text { heulandite }\end{array}$ & $* * * *$ & Tabular crystals or fibers in vesicules & Occurs as radial fibrous aggregates in plagioclase. Alteration minerals \\
\hline Analcime & $* * *$ & Etched and partial dissolution & Occurs as aggregates in plagioclase. Alteration minerals \\
\hline Clinopyroxene & *** & Adherent particles and cracks & Phenocrysts and groundmass \\
\hline Quartz & ** & Several micro-textures & Groundmass \\
\hline Magnetite & ** & $\begin{array}{l}\text { Clay coverage, small cracks and adherent } \\
\text { particles }\end{array}$ & Groundmass \\
\hline Calcite & - & - & $\begin{array}{l}\text { Alteration mineral areas replacement in the groundmass and } \\
\text { phenocrysts }\end{array}$ \\
\hline Olivine & * & Cracks and progressively altered forms & $\begin{array}{l}\text { Crystals are progressively } \\
\text { altered to pseudomorphs }\end{array}$ \\
\hline Others & * & $\begin{array}{l}\text { Clay minerals } \\
\text { and apatite }\end{array}$ & Vermiculite, iddingsite, smectite, chlorite. Alteration minerals \\
\hline
\end{tabular}


concentrations of $\mathrm{Ca}$ and occasional $\mathrm{Fe}, \mathrm{Mg}$ and $\mathrm{K}$. Analcime crystals have a varied morphology (Fig. 3e, f). Among the features present, isolated isometric crystals are common (Fig. 3e), which suggests provenance from volcanic rock fragments, probably compatible with crystallization from volcanic glass, clay minerals and or plagioclase (Sheppard \& Hay 2001). Examination via SEM reveals that the outer surface of analcime crystals are both etched and partially dissolved (Fig. 3f). The heulandite-clinoptilolite minerals, probably weathered from zeolite tuffs, are present as tabular crystals (Fig. 3g) and as fibres in the vesicles of rock fragments (Fig. 3h).

Magnetite, a common mineral found in the study area, is present as euhedral crystals in rock fragments. Clay coverage as adhering material and small cracks were also found in some crystals (Fig. 3i, j).

Clay minerals in the samples are mainly phyllosilicates such as smectite, chlorite and illite (Fig. 3k, i). The smectite tends to be Fe-rich and therefore possibly belongs to the nontronite group.

\section{XRD analysis}

The XRD analysis of the fine fraction $(<2 \mu \mathrm{m})$ from the sediments sampled here showed very similar characteristics to the outcrops of the study site. A summary of mineralogical data is given in Table 2 . The mineral assemblage consists mainly of plagioclase followed by clinopiroxene-heulandite, analcime, clinopyroxene, quartz, magnetite and small amounts of alteration minerals (smectite, chlorite).

\section{Petrography of source rocks}

The outcrops of the Fildes Peninsula are mainly volcanic rock consisting of andesite and basalt-andesite (Fig. 4). These outcrops are the source of sediments transported to Profound Lake. The distribution of rock samples is shown in Fig. 1.

Whole rock analyses show mainly clinopyroxene basalt-andesite (R1, R3 and R2), trachyandesite (R5) and clinopyroxene-andesite (R2, R7 and R4), showing porphyritic textures. The clinopyroxene-andesite consists mainly of phenocrysts of plagioclase and clinopyroxene (Fig. 4a). The groundmass of the specimen contains unaltered plagioclase, clinopyroxene, olivine and abundant opaque minerals and magnetite. The plagioclase is commonly andesine and labradorite, which are present as replacement minerals in the groundmass and phenocrysts. Zeolite of variable composition usually occurs as radial fibrous aggregates in plagioclase, while calcite is an aggregate in plagioclase, particularly possibly deriving $\mathrm{Ca}$ from anorthoclase. Olivine crystals are progressively altered to pseudomorphs of iddingsite and mafic phyllosilicates (Fig. 4b). Anhedral magnetite has been partially altered to hematite.

The clinopyroxene basalt-andesite consists mainly of phenocrysts of plagioclase and fragmented clinopyroxene (Fig. 4c). The groundmass contains plagioclase, pyroxene, biotite, magnetite and interstitial glass replaced by clay minerals (Fig. 4d), particularly vermiculite. The samples R1 and R3 show alteration minerals, comprising calcite and pumpellyite in groundmass and plagioclase phenocrysts. These samples exhibit porphyritic textures, occasionally with a megascopically glassy groundmass (Fig. 4e). The plagioclase phenocrysts exhibit the typical sieve texture (Fig. 4f) and significant weathering, and are progressively altered to pseudomorphs of zeolites, vermiculite and mafic phyllosilicates. Zeolites typically occur as radial fibrous aggregates replacing plagioclase (Fig. 4g).

The trachyandesite is composed of plagioclase and clinopyroxene phenocrysts. The groundmass contains plagioclase, apatite, magnetite and interstitial glass replacements (Fig. $4 \mathrm{~h}$ ).

\section{Discussion}

\section{Origin of the grain microfeatures}

SEM proved useful to better understand grain provenance, erosion, transportation and depositional processes for palaeoclimate reconstruction (e.g., Whalley \& Krinsley 1974; Mahaney 1990a; Mahaney 2002; Vos et al. 2014). In this study we have used it to establish source areas and to test the alteration of grains after bedrock release and transport to the lacustrine system of Lake Profound. Surface micro-textures embedded in grains may, in some cases, relate to specific mechanical and chemical processes, whereas others may follow the principle of equifinality - that is, as products of several geological processes. Angular grains, with arcuate cracks, breakage blocks, oriented scratches and grooves and sub-parallel to parallel striations are indicative of the glacial environment. Breakage blocks may also result from bedrock release and mechanical weathering (Mahaney 2002). The mechanical action of glaciers includes two common processes that affect the surface texture of minerals: abrasion and crushing, also known as fracturing (e.g., Krinsley \& Dornkamp 1973; Mahaney 2002; Immonen et al. 2013). The effects of abrasion and crushing are clearly engraved in the surface of the grains in this study, including high relief, curved and straight grooves that reflect sustained high shear stress and conchoidal fractures on the rounded edges and on sharp edges.

Straight grooves are problematic, however, in that they often have a tectonic origin, and are related to 


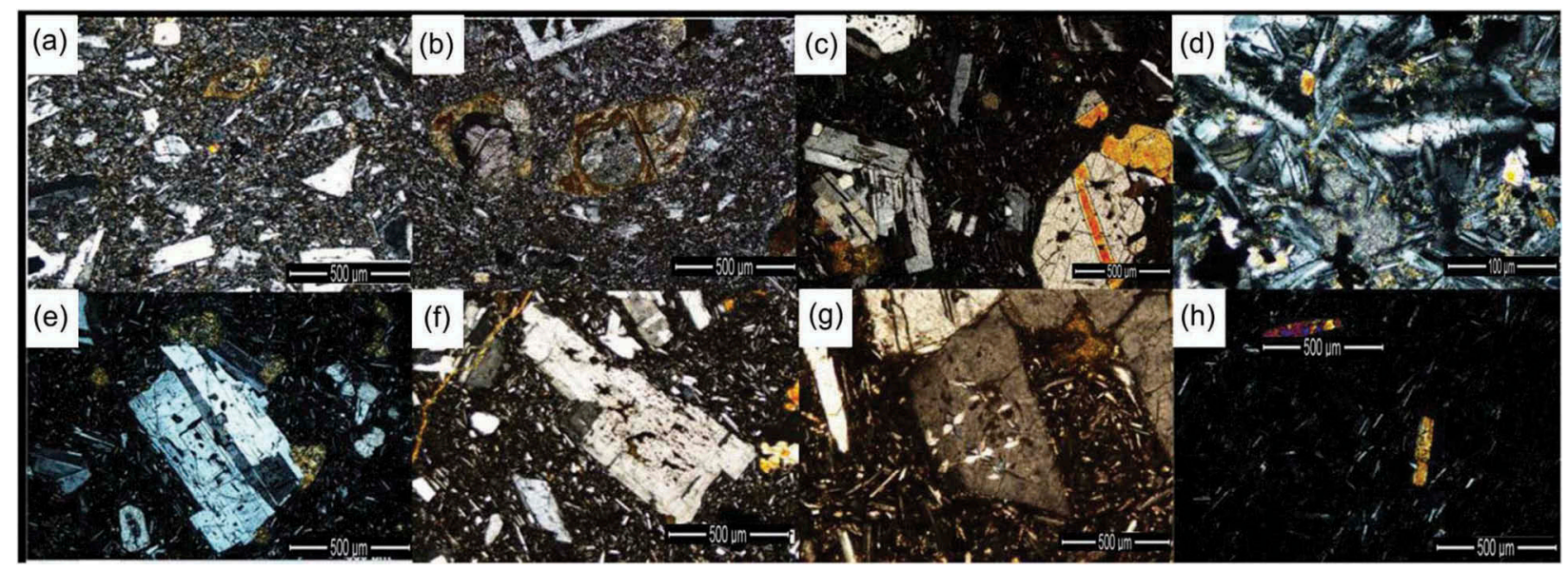

Figure 4. Petrological analysis: (a) clinopyroxene andesite with porphyritic texture; (b) fragmented pyroxene and olivine pseudomorphs completely replaced; (c) basaltic andesite with porphyritic texture; (d) groundmass containing plagioclase, magnetite and interstitial glass replaced by clay minerals; (d) porphyritic texture with megascopically glassy groundmass; (f) sieve texture in plagioclase; $(\mathrm{g})$ occurrence of the zeolites as radial fibrous aggregates in plagioclase; $(\mathrm{h})$ trachyandesite.

fault systems (Mahaney 2002), whereas curved grooves, like striae in pebbles and bedrock, are considered to have glacial origins. Conchoidal fractures, on the other hand, are known on aeolian sands; however, when seen in a high percentage of sand surfaces in conjunction with sub-parallel linear fractures, the probability is that they carry a glacial signature (Mahaney 2002). Because conchoidal fractures in this suite of samples are both fresh and weathered, the latter coated by amorphous silica and clay minerals, it is clear a significant population of samples are reworked, possibly sourced from a warmer and more humid palaeoclimate and possibly involving aeolian transport.

Minerals such as quartz, zeolite, plagioclase and magnetite present solution pits, precipitation coatings and dissolution etching, all comprising alteration products of chemical weathering of source rock during contact with external factors, presumably present at the time of ice withdrawal when source rock was exposed to the atmosphere and biosphere. This type of chemical alteration of minerals was previously reported in lacustrine sediment from the Fildes Peninsula by Alfonso et al. (2015). Alternatively, such weathering may be linked to one or more interglacial periods of the Pleistocene prior to ice readvance, bedrock release, entrainment and transport, with grain overprinting to the lake. It is also possible some extreme forms of weathering, such as deep solution pits and widespread dissolution etching on grains analysed, may be pre-Pleistocene, and hence formed in warmer climates with variable precipitation.

Magnetite often contains variable clay mineral coatings on what are otherwise clean internal surfaces. Chemically altered micro-textures therefore indicate a considerable degree of weathering subsequent to glacial erosion from bedrock sources, and it is these micro-features that may possibly even predate glaciation in Antarctica. Similarly, Asthana et al. (2014) showed evidence of chemical activity after the deposition of grains in the glacial lacustrine environment of the Antarctic. According to Woronko (2007), chemical weathering in polar regions results mainly from the development of precipitation on the surface of sand grains. Therefore, grains affected by the mechanical action of glaciers could alter their shape and degree of rounding by precipitation as they are coated by a thick layer of amorphous silica. The diatom-embedded quartz, which supports the previous findings of Schmidt et al. (1990), may relate to lacustrine precipitation of $\mathrm{SiO}_{2}$, followed by cementation, and/or compression by overriding ice at some time in the past.

The considerable amount of observed chemically altered micro-textures on some grains relative to fresh surfaces on others indicates a complex history of pre-weathering, followed by glacial or glaciofluvial transport to the lake and posterior dissolution (Fig. 5). Glaciofluvial action produced grain-grain collisions resulting in $\mathrm{V}$-shaped percussion cracks (e.g., Mahaney 2002; Vos et al. 2014), which might also be related to the process of grain collision in icemelt water (e.g., Mahaney et al. 1988). In fact, mass wasting and rock fall events are all transport related but mainly achieved through glacial advance rather than glaciofluvial processes (Van Hoesen \& Orndorff 2004). In other instances, mechanical weathering caused by grain-to-grain contact may leave hidden fractures in grain surface skins (Peternecht \& Tietz 2011), later following dissolution to be interpreted as bona fide fractures, such as chattermarks described by Folk (1975), but not always attributable to 


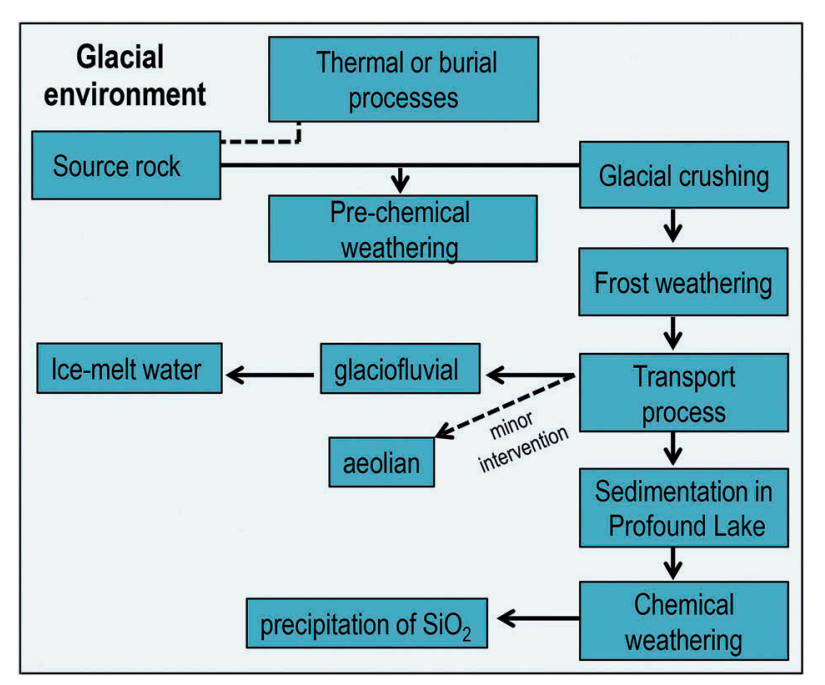

Figure 5. Diagram showing the origin of sediments accumulated in Lake Profound.

glaciation, which could render them a hybrid mechanical-chemical entity.

According to Woronko (2007), chemical weathering in polar regions results mainly from the development of precipitation on the surface of sand grains. However, the question of whether precipitation on sand grains can lead to grain weathering remains open and subject to considerable future research.

Nevertheless, there are micro-features caused by pre-chemical weathering that further react during contact with external factors at the time of ice withdrawal, when source rock is exposed to the atmosphere and biosphere. Alternatively, such weathering may be linked to one or more interglacial periods of the Pleistocene prior to ice readvance, bedrock release, entrainment and transport, with grain overprinting to the lake. It is also possible some extreme forms of weathering, such as deep solution pits and widespread dissolution etching on grains analysed, may be pre-Pleistocene, and hence formed in warmer climates with variable precipitation.

\section{Grain provenance and source}

Minerals like quartz, plagioclase, zeolites and magnetite commonly contain adhering particles, which are normally considered to be glacially ground remnants of source rocks. Most likely, these minerals have suffered glacial transport with decreasing temperatures or lack of time for collision in meltwater streams that might remove small particulate matter. EDS analysis shows that the adhering particles have a primary composition of $\mathrm{Si}, \mathrm{Al}, \mathrm{K}, \mathrm{Na}$ and $\mathrm{Fe}$, which is in agreement with XRD and EDS performed on the country rock.

Alteration minerals such as clays, zeolites, calcite and mafic phyllosilicates were most probably precipitated in the bedrock, either by thermal or burial processes (Bastias et al. 2016), or alternatively for the clay minerals by weathering during one or more inter-glacials, possibly in pre-Neogene time. Bastias et al. (2013) and Fuentes et al. (2015) concluded from Livingston Island samples that these mineral occurrences might be related to a burial process overprinted by hydrothermal activity. Although distance between the Collins Glacier and Profound Lake is minimal, the actual source of each sample can only be inferred. Clay mineral genesis is little known in the region and it is possible that clay species have developed in a cold climate over long periods of time, or might be produced in narrow inter-glacial periods via retreat of ice, perhaps even in pre-Pleistocene times. Jeong et al. (2004) suggested that expandable clay species, such as smectite, could have been derived from the erosion of hydrothermally altered volcanic rock. Further afield, in the mountains of the Antarctic Dry Valley, berthierine has been detected in weathering rinds of the New Mountain area (Mahaney \& Schwartz 2016) dating to the Late Oligocene (Mahaney 2015a), although in felsic sediment. Forming kaolinite from volcanic sediment might be problematic, but halloysite-metahalloysite is known to form from volcanic rock in cold climates, although under milder temperatures than in sub-polar climates. With additional precipitation, as on Mt. Kenya $\left(0^{\circ} 10^{\prime} \mathrm{S} ; 37^{\circ} 20^{\prime} \mathrm{E}\right)$, halloysite-metahalloysite clay requires ca. $100 \mathrm{Ky}$ to form (Mahaney 1989a, 1990b, 1991). Moreover, halloysite-metahalloysite and gibbsite are observed to form on weathered volcanic glass and occasionally on feldspar crystals (Vortisch et al. 1987) in cold climates, but neither halloysite-metahalloysite nor gibbsite were observed in the suite of samples studied here.

The clay mineral weathering sequence depicted here follows the well-known and referenced sequence of hydrous mica $\rightarrow 10 \AA$ illite $\rightarrow$ smectite $\rightarrow$ vermiculite $\rightarrow$ chlorite stages (Jackson 1967). Following weathering index 4 (biotite), to 7 (illite), 8 (vermiculite), 9 (smectite inclusive of various clay species such as are identified here), the final clay mineral weathering stage 10 (kaolinite-halloysite) was not reached, either because of a downturn in climate coupled with decreasing temperatures or a lack of time. While clay mineral genesis in polar regions is better known from marine sediments (Ehrmann 1998; Winkler et al. 2002; Ehrmann et al. 2005), palaeosol clay mineral terrestrial sequences in polar regions are few and far between (Mahaney, Dohm et al. 2001; Mahaney et al. 2009), mainly because in mountains close to the inland ice, resident clays in palaeosols are allochthonous, sourced from afar with genesis having occurred under more temperate climates. Even with the minor amount of mica present in this study, it is significant that clay mineral genesis has led to the production of appreciable amounts of smectite and 
other 2:1 and 2:1:1 minerals, such species occupying a mid-position in Jackson's (1967) weathering sequence. This may well indicate that pre-weathering occurred in the early stage of temperate glacial growth in Antarctica, or before the subsequent onset of dry, cold conditions starting after the mid-Miocene climatic optimum (Mahaney 2015a), the transition slowing sediment weathering rates to near $1 \mathrm{~cm} / 1 \mathrm{My}$ in paleosols (Mahaney, Stewart et al. 2001). The presence of vermiculite may signal either an intermediate weathering intergrade between smectite and chlorite and/or the presence of conifers, as vermiculite is often associated with coniferous forest (Mahaney 2015b; Mahaney unpubl. ms).

\section{Conclusions}

The grain history elucidated by our analyses reflects the release of source rock-andesite and basalt-andesite-by physical weathering, assisted to an unknown degree by chemical processes and followed by glacial, glaciofluvial and aeolian action, with ultimate sedimentation in Lake Profound. Bedrock erosion may have been favoured by the presence of pre-weathered material resulting from both mechanical and chemical processes, so that the full history recorded on some grains is one of weathering-release by mechanical strain from frost or glacial rasping, followed by transport with significant overprinting resulting in superficial grain skin, and sedimentation followed again by diagenesis, particularly the growth of diatoms in quartz dissolution cavities.

The mineralogical composition of the most common minerals found in the lacustrine sediment is consistent with those found in andesite and basaltandesite bedrock.

Mineral weathering in polar areas is complex and open to different interpretations. The available data discussed here includes a considerable range and intensity of pre-weathered and weathered surfaces based on differences in dissolution alone. Alteration minerals such as zeolites, mafic phyllosilicate and clay minerals were most likely eroded from the bedrock, where they were first formed through precipitation, either by thermal or burial processes, perhaps predating glaciation. Clay minerals may have more complex histories related to palaeoclimate and resulting weathering events, but mostly their genesis is considered to come from weathering of micarich sediment, and over very long time frames and in environments with higher weathering kinetic energy than today. The evidence indicates that dissolution of quartz and hydrolysis of micas-plagioclases led to the release of metal cations forming hydroxides, followed by a combination of $\mathrm{Si}-\mathrm{Al}$ breakages and recrystallization of Si:Al into 2:1 and 2:1:1 clay minerals. All this seems to have occurred without the genesis of measurable halloysite-metahalloysite, a common long-term clay product from weathering of volcanic rock.
Frost weathering involves a complex combination of mechanical release, perhaps preceded by chemical processes that weakened rock fabric but must have followed the limitations outlined above. Some cracks in grains of different lithologies and of large dimensions may relate to frost cycles on the lake. Fracture faces seen on about $10 \%$ of grains analysed may relate to frost weathering of bedrock, such micro-textures having been retained almost without modification from glacial transport.

\section{Acknowledgements}

We thank Jackson Ojeda, Yaneth Vasquez, Eloy Sira and Lisbeth Lozada for their support.

\section{Funding}

This study was supported by the Venezuelan Antarctic Program of the Ministerio del Poder Popular para la Ciencia, Tecnología e Innovación. JB acknowledges the Instituto Antártico Chileno project INACH RT0614, which supported his participation.

\section{ORCID}

Joaquin Bastias (D) http://orcid.org/0000-0001-6678-3173

\section{References}

Alfonso J.A., Vasquez Y., Hernandez A.C., Mora A., Handt H. \& Sira E. 2015. Geochemistry of recent lacustrine sediments from Fildes Peninsula, King George Island, maritime Antarctica. Antarctic Science 27, 462-471.

Asthana R., Shrivastava P.K., Srivastava H.B., Beg M.J. \& Kumar P. 2014. Hydrochemistry and sediment characteristics of polar periglacial lacustrine environments on Fisher Island and Broknes Peninsula, East Antarctica. Advances in Polar Science 24, 281-295.

Barton C.M. 1961. The geology of King George Island, South Shetland Islands. Preliminary Reports of the Falkland Island Dependencies Survey 12, 1-18.

Barton C.M. 1965. The geology of South Shetland Islands. III. The stratigraphy of King George Island. British Antarctic Survey Scientific Reports. Vol. 44. London: British Antarctic Survey.

Bastias J., Fuentes F., Aguirre L., Hervé F., Demant A., Deckart K. \& Torres T. 2016. Very low-grade secondary minerals as indicators of palaeo-hydrothermal systems in the Upper Cretaceous volcanic succession of Hannah Point, Livingston Island, Antarctica. Applied Clay Science 134, 246-256.

Bastias J., Fuentes F., Aguirre L., Hervé F., Fernandoy F. \& Demant A. 2013. Zeolites and mafic phyllosilicates in Livingston Island, Antarctica. Mineralogical Magazine 77, 666.

Biscaye P.E. 1965. Mineralogy and sedimentation of recent deep sea clay in the Atlantic Ocean and adjacent seas and oceans. Geological Society American Bulletin 76, 806-832.

Ehrmann W. 1998. Implications of late Eocene to early Miocene clay mineral assemblages in McMurdo Sound (Ross Sea, Antarctica) on paleoclimate and ice dynamics. Palaeogeography, Palaeoclimatology, Palaeoecology 139, 213-231. 
Ehrmann W.U., Setti M. \& Marinoni L. 2005. Clay minerals in Cenozoic sediments off Cape Roberts (McMurdo Sound, Antarctica) reveal paleoclimatic history. Palaeogeography, Palaeoclimatology, Palaeoecology 229, 179-250.

Folk R.L. 1975. Glacial deposits identified by chattermark tracks in detrital grains. Geology 3, 475-479.

Fuentes F., Chavez G., Bastias J., Aguirre L. \& Hervé F. 2015. Very low-grade hydrothermal metamorphism of Cenozoic volcanics in Fildes Peninsula, King George Island, Antarctica. Goldschmidt Abstracts 2015, 963.

Haase K., Beier C., Fretzdorff S., Smellie J. \& GarbeSchönberg D. 2012. Magmatic evolution of the South Shetland Islands, Antarctica, and implications for continental crust formation. Contributions to Mineralogy \& Petrology 163, 1103-1119.

Helland P.E. \& Holmes M.A. 1997. Surface textural analysis of quartz sand grains from ODP Site 918 off the southeast coast of Greenland suggests glaciation of southern Greenland at $11 \mathrm{Ma}$. Palaeogeography, Palaeoclimatology, Palaeoecology 135, 109-121.

Helland P.E., Huang P.H. \& Diffendal R.F. 1997. SEM analysis of quartz sand grain surface textures indicates alluvial/colluvial origin of the Quaternary "glacial" boulder clays at Huangshan (Yellow Mountain), EastCentral China. Quaternary Research 48, 177-186.

Hutchinson C.S. 1974. Laboratory handbook of petrographic techniques. New York: Wiley.

Immonen N. 2013. Surface micro-textures of ice-rafted quartz grains revealing glacial ice in the Cenozoic Arctic. Palaeogeography, Palaeoclimatology, Palaeoecology 374, 293-302.

Jackson M. 1967. Chemical composition of soils. In F.E. Bear (ed.): Chemistry of the soil 2nd edn. Pp. 71-141. New York: Reinhold Publishing.

Jackson M. 2005. Soil chemical analysis: advanced course. 2nd edn. Madison: University of Wisconsin Press.

Jeong G.Y., Yoon H.I. \& Lee S.Y. 2004. Chemistry and microstructures of clay particles in smectite-rich shelf sediments, South Shetland Islands, Antarctica. Marine Geology 209, 19-30.

Krinsley D.H. \& Doornkamp J.C. 1973. Atlas of quartz sand surface textures. London: Cambridge University Press.

Last W.M. 2001. Mineralogical analysis of lake sediments. In W.M. Last \& J.P. Smol (eds.): Tracking environmental change using lake sediments. Physical and geochemical methods. Vol. 2. Dordrecht: Kluwer Academic Publishers.

Machado A., Chemale F., Conceição R.V., Kawaskita K., Morata D., Oteíza O. \& Van Schmus W.R. 2005. Modeling of subduction components in the genesis of the Meso-Cenozoic igneous rocks from the South Shetland Arc, Antarctica. Lithos 82, 435-453.

Machado A., Chemale Jr. F., Lima E.F. \& Figuereido A.M. G. 1998. Petrologia das rochas vulcânicas da Península Fildes, Ilha Rei George, Antártica. (Petrology of the volcanic rocks of Fildes Peninsula, King George Island, Antarctica.) Pesquisas 25, 35-42.

Mahaney W.C. 1989. Quaternary glacial geology of Mount Kenya. In W.C. Mahaney (ed.): Quaternary and environmental research on East African mountains. Pp. 121-140. Rotterdam: Balkema.

Mahaney W.C. 1990a. Macrofabrics and quartz microstructures confirm glacial origin of Sunnybrook drift in the Lake Ontario basin. Geology 18, 145-148.

Mahaney W.C. 1990b. Ice on the Equator. Ellison Bay, WI: William Caxton Ltd.
Mahaney W.C. 1991. Distributions of halloysite-metahalloysite and gibbsite in tropical mountain paleosols: relationship to Quaternary paleoclimate. Palaeogeography, Palaeoclimatology, Palaeoecology 88, 219-230.

Mahaney W.C. 1995. Pleistocene and Holocene glacier thicknesses, transport histories and dynamics inferred from SEM micro-textures on quartz particles. Boreas 24, 293-304.

Mahaney W.C. 2002. Atlas of sand grain surface textures and applications. Oxford: Oxford University Press.

Mahaney W.C. 2015a. Pedological Iron/Al extracts, clastanalysis and Coleoptera from Antarctic paleosol 831: evidence of a Middle Miocene or earlier climatic optimum. Journal of Geology 123, 113-132.

Mahaney W.C. 2015b. Clay mineral evidence of a bioclimatically-disrupted soil, Rouge River basin, south-central Ontario, Canada. Geomorphology 228, 189-199.

Mahaney W.C., Claridge G. \& Campbell I. 1996. Micro-textures on quartz grains in tills from Antarctica. Palaeogeography, Palaeoclimatology, Palaeoecology 121, 89-103.

Mahaney W.C., Dohm J., Kapran B. \& Hancock R.G.V. 2009. Secondary Fe and Al in Antarctic paleosols: correlation to Mars with prospect for the presence of life. Icarus 203, 320-330.

Mahaney W.C., Dohm J.M., Baker V.R., Newsom H.E., Malloch D., Hancock R.G.V., Campbell I., Sheppard D. \& Milner M.W. 2001. Morphogenesis of Antarctic paleosols: Martian analogue. Icarus 154, 113-130.

Mahaney W.C. \& Schwartz S. 2016. Paleoclimate of Antarctica reconstructed from clast weathering rind analysis. Palaeogeography, Palaeoclimatology, Palaeoecology 446, 205-212.

Mahaney W.C., Stewart A. \& Kalm V. 2001. Quantification of SEM micro-textures useful in sedimentary environmental discrimination. Boreas 30, 165-171.

Mahaney W.C., Vortisch W. \& Julig P. 1988. Relative differences between glacially crushed quartz transported by mountain and continental ice-some examples from North America and East Africa. American Journal of Science 288, 810-826.

Mahesh B.S., Warrier A.K., Mohan R., Tiwari M., Anila B., Aswathi C., Asthana R., \& Ravindra R. 2015. Response of long lake sediments to antarctic climate: a perspective gained from sedimentary organic geochemistry and particle size analysis. Polar Science 9, 359-367.

Mäusbacher R., Muller J., Munnich J. \& Schmidt R. 1989. Evolution of postglacial sedimentation in Antarctic lakes (King George Island). Zetschrift für Geomorphologie 33, 219-234.

Michel R.F.M., Schaefer C.E.G.R., López-Martínez J., Simas F.N.B., Haus N.W., Serrano E. \& Bockheim J.G. 2014. Soils and landforms from Fildes Peninsula and Ardley Island, maritime Antarctica. Geomorphology 225, 76-86

Monien P., Schnetger H., Brumsack H.R., Hass C. \& Huhn G. 2011. A geochemical record of late Holocene palaeoenvironmental changes at King George Island (maritime Antarctica). Antarctic Science 23, 255-267.

Peternecht K. \& Tietz G. 2011. Chattermark trails and surface features on detrital quartz grains indicative of a tropical climate. Journal Sedimentary Research 81, 153-158.

Pettijohn F.J., Potter P.E. \& Siever R. 1987. Sand and sandstone. 2nd edn. New York: Springer.

Schmidt R., Mausbacher R. \& Muller J. 1990. Holocene diatom flora and stratigraphy from sediment cores of two Antarctic lakes (King George Island). Journal of Paleolimnology 3, 55-90. 
Sheppard R.A. \& Hay R.L. 2001. Formation of zeolites in open hydrologic systems. In D.L. Bish \& D.W. Ming. (eds.): Natural zeolites: occurrence, properties, application. Reviews in Mineralogy Geochemistry. Vol. 45. Pp. 261-276. Washington, D.C.: Mineralogical Society of America and the Geochemical Society.

Smalley I.J. 1966. The properties of glacial loess and formation of loess deposits. Journal of Sedimentary Research 36, 669-676.

Smellie J.L., Pankhurst R.J., Thomson M.R.A. \& Davies R. E.S. 1984. The geology of the South Shetland Islands. VI. Stratigraphy, geochemistry and evolution. British Antarctic Survey Scientific Reports 87. Cambridge: British Antarctic Survey.

Soil Classification Working Group 1998. The Canadian system of soil classification. Agriculture and Agri-Food Canada Publication 1646. 3rd edn. Ottawa: NRC Research Press.

Solari M., Hervé F., Martinod J., Le Roux J.P., Ramírez L. \& Palacios C. 2008. Geotectonic evolution of the Bransfield Basin, Antarctic Peninsula: insights from analogue models. Antarctic Science 20, 185-196.

Staff S.S. 1999. Soil taxonomy. A basic system of soil classification for making and interpreting soil surveys. Agriculture Handbook. Vol. 436. 2nd edn. Washington, D.C.: US Department of Agriculture.

Streckeisen A. 1976. To each plutonic rock its proper name. Earth-Science Reviews 12, 12-33.

Trewin N. 1988. Use of the scanning electron microscope in sedimentology. In M. Tucker (ed.): Techniques in sedimentology. Pp. 229-273. Oxford: Blackwell Science Publications.

Van Hoesen J.G. \& Orndorff R.L. 2004. A comparative SEM study on the micromorphology of glacial and non-glacial clasts with varying age and lithology. Canadian Journal of Earth Science 41, 1123-1139.

Vortisch W., Mahaney W.C. \& Fecher K. 1987. Lithology and weathering in a paleosol sequence on Mount Kenya. Geologica et Paleotologica 21, 245-255.
Vos K., Vandenberghe N. \& Elsen J. 2014. Surface textural analysis of quartz grains by scanning electron microscopy (SEM): from sample preparation to environmental interpretation. Earth Science Reviews 128, 93-104.

Whalley W.B. \& Krinsley D.H. 1974. A scanning electron microscope study of surface textures of quartz grains from glacial environments. Sedimentology 21, 87-105.

Winkler A., Wolf-Welling T.C.W., Stattegger K. \& Thiede J. 2002. Clay mineral sedimentation in high northern latitude deep-sea basins since the Middle Miocene (ODP Leg 151, NAAG). International Journal of Earth Sciences 91, 133-148.

Woronko B. 2007. Typy mikromorfologii powierzchni ziarn kwarcowych frakcji pylastej i ich wartość interpretacyjna. (Micromorphology types of the surface of quartz grains of the silty fraction and their interpretive value.) In E. Mycielska-Dowgiałło \& J. Rutkowski (eds.): Badania cech teksturalnych osadów czwartorzkdowych $i$ wybrane metody oznaczania ich wieku. (Textural features of Quaternary sediments and some methods for determining their age.) Pp. 181-204. Warsaw: Wydawnictwo Szkoły Wyższej Przymierza Rodzin.

Woronko B. 2012. Micromorphology of quartz grains as a tool in the reconstruction of periglacial environment. In P. Churski. (ed.): Contemporary issues in Polish geography. Pp. 111-131. Poznań: Bogucki Wydawnictwo Naukowe.

Woronko B. 2016. Frost weathering versus glacial grinding in the micromorphology of quartz sand grains. Processes and geological implications. Sedimentary Geology 335, 103-119.

Woronko B. \& Hoch M. 2011. The development of frostweathering microstructures on sand-sized quartz grains: examples from Poland and Mongolia. Permafrost and Periglacial Processes 22, 214-227.

Woronko B. \& Pisarska-Jamroży M. 2016. Micro-scale frost weathering of sand-size quartz grains. Permafrost and Periglacial Processes 27, 109-122. 